20 National Research Council. Recommended dietary allowances. 10th ed. Washington, DC: National Academy Press, 1989.

21 McLaughlin PJ, Weihrauch JL. Vitamin E content of foods. f Am Diet Assoc 1979;75:647-65.

22 Järvinen R, Seppänen R, Knekt P. Short-term and longterm reproducibility of dietary history interview data. In term reproducibility of diet

23 Brockington F. World health. Appendix VIII. The in ternational standard classification of occupations, 2nd edn London: Churchill, 1967:331-9.

24 Cohen J, Cohen P. Applied multiple regression/correlation analysis for the behavioral sciences. New York: John Wiley \& Sons, 1975.

25 Pao EM, Mickle SJ, Burk MC. One-day and 3-day nutrien intakes by individuals - Nationwide Food Consumption Survey findings, spring 1977. F Am Diet Assoc 1985;85: 313-24.

26 Murphy SP, Subar AF, Block G. Vitamin E intakes and sources in the United States. Am f Clin Nutr 1990;52 361-7.

27 Bolton-Smith C, Woodward M, Brown CA, TunstallPedoe $H$. Nutrient intake by duration of ex-smoking in the Scottish heart health study. BrF Nutr 1993;69:315-32.

28 Knekt P, Seppänen R, Aaran R-K. Determinants of serum alpha-tocopherol in Finnish adults. Prev Med 1988;17: alpha-tocop.

29 Järvinen R, Knekt P, Seppänen R, Heinonen M, Aaran R-K Dietary determinants of serum $\beta$-carotene and serum retinol. Eur f Clin Nutr 1993;47:31-41.

30 Bolton-Smith C, Smith WCS, Woodward M, TunstallPedoe $\mathrm{H}$. Age trends in nutrient intakes for non-manual and manual occupational groups: the Scottish heart health study (abstract). Proc Nutr Soc 1990;49:63A.

31 Seppänen R. Nutrition in Finland. (In Finnish.) Duodecim 1982;98:1666-73.

32 Aro S, Räsänen L, Telama R. Social class and changes in health-related habits in Finland in 1973-1983. Scand 7 Soc Med 1986;14:39-47.

33 Braddon FEM, Wadsworth MEJ, Davies JMC Cripps HA. Social and regional differences in food and alcohol consumption and their measurement in a national birth consumption and their measurement in a national birth

34 Hulshof KFAM, Löwik MRH, Kok FJ, et al. Diet and other life-style factors in high and low socio-economic groups (Dutch nutrition surveillance system). Eur f Clin Nutr 1991;45:441-50.

35 Preston AM. Cigarette smoking - nutritional implications. Prog Food Nutr Sci 1991;15:183-217.

36 Stryker WS, Kaplan LA, Stein EA, Stampfer MJ, Sober A, Willett WC. The relationship of diet, cigarette smoking and alcohol consumption to plasma beta-carotene and alpha-tocopherol levels. Am $\mathcal{F}$ Epidemiol 1988;127:283-96.

37 Schectman G. Estimating ascorbic acid requirements for cigarette smokers. Ann NY Acad Sci 1993;686:335-45.

38 Subar AF, Harlan LC, Mattson ME. Food and nutrient intake differences between smokers and non-smokers in the US. Am 7 Public Health 1990;80:1323-9.

39 Cade JE, Margetts BM. Relationship between diet and smoking - Is the diet of smokers different? $\mathcal{f}$ Epidemiol Community Health 1991;45:270-2.

40 Herbeth B, Chavance M, Musse N, Vernhes G. Determinants of plasma retinol, beta-carotene, and alphaterminants of plasma retinol, beta-carotene,

41 Knekt P. Vitamin $\mathrm{E}$ and smoking and the risk of lung Knekt P. Vitamin $\mathrm{E}$ and smoking and the

42 Kato I, Tominaga S, Suzuki T. Characteristics of past smokers. Int $\mathcal{F}$ Epidemiol 1989;18:345-54.

43 Baecke JAH, van Staveren WA, Burema J. Food consumption, habitual physical activity, and body fatness in young Dutch adults. Am $\mathcal{F}$ Clin Nutr 1983;37:278-86.

44 Prentice AM, Black AE, Coward WA, et al. High level of energy expenditure in obese women. BMf 1986;292 $983-7$.

\title{
Cancer patient survival by socioeconomic status in seven countries: a review for six common cancer sites
}

Carola T M Schrijvers, Johan P Mackenbach

\begin{abstract}
Study objective - To study the size and consistency of socioeconomic differences in cancer patient survival as reported in published studies.

Methods - A systematic review was coriducted. Several criteria were developed to select the study material, which resulted in 14 reports on socioeconomic differences in survival for cancers of the colon, rectum, lung, prostate, breast, and cervix. These present results on patients from the United States, Japan, Australia, United Kingdom, Sweden, Finland, and Germany. The results are summarised in a relative risk of dying or survival ratio for
\end{abstract}

the lowest socioeconomic status group compared with the highest.

Results - For cancers of the colon, rectum, breast, and cervix, patients from higher socioeconomic status groups had a better survival. For lung cancer and cancer of the prostate, results were unclear.

Conclusion-Socioeconomic differences in cancer survival are generally small and their contribution to socioeconomic differences in cancer mortality is probably small too. These findings have implications for the type of health policy measures which should be taken to reduce socioeconomic differences in cancer mortality.

Corrigendum: An article was published in the October issue entitled "Cancer patient survival by socioeconomic status in The Netherlands: a review for six common cancer sites" ( $F$ Epidemiol Community Health 1994; 48: 441-6). This title was incorrect and misleading. The corrected title is printed above, together with the abstract. 